\title{
Altitudinal Distribution of Loranthaceae Parasites of Woody Plants on the Mandara Mountains in the Far North Region, Cameroon
}

Djibrilla Mana*, Souare Konsala, Ibrahima Adamou

Department of Biological Sciences, Faculty of Sciences, University of Maroua, P.O.Box:814 Maroua, Cameroon

Article History
Received: 16.07 .2020
Accepted: 08.08 .2020
Published: 14.10 .2020
Journal homepage:
http://www.easpublisher.com/easjals/
Quick Response Code

\begin{abstract}
Despite the importance of Loranthaceae parasites of woody plants in traditional Africa medicine, very few studies have been carried out on their diversity in the Sudano-Sahelian zone of Cameroon. The study aims to examine the diversity of Loranthaceae parasites of woody plants and determine their altitudinal distribution over the Mandara Mountains in the Far North region, Cameroon. It took place in nine (09) borough spread over four Departments of the Mandara Mountains. The experimental design is made up of 15 Hills (altitude $\geq 1000 \mathrm{~m}$ ), representing the main treatment. The 15 Hills are chosen at the rate of one Mount every $10 \mathrm{~km}$ in the whole of the Mandara Mountains. The Mounts were grouped by three according to the level of altitude of the plain of each Mount to find five Mounts (Mount $1(<500 \mathrm{~m}=$ Mount $1+$ Mount $2+$ Mount 15) ; Mount $2([500 \mathrm{~m}-600 \mathrm{~m}$ [= Mount $4+$ Mount $5+$ Mount 3$)$; Mount 3 $([600 \mathrm{~m}-700 \mathrm{~m}[=$ Mount $6+$ Mount $7+$ Mount 13); Mount $4([700 \mathrm{~m}-800 \mathrm{~m}[=$ Mount $8+$ Mount $9+$ Mount 14) ; Mount 5 (> $800 \mathrm{~m}=$ Mount $10+$ Mount $11+$ Mount 12)). On each Hill, two flanks (East and West) were chosen and constituting the secondary treatment, and on each flank, $50 \mathrm{~m} \mathrm{x} 20 \mathrm{~m}$ transects (repetitions) were installed by altitude level (tertiary treatment) starting with the plain, to the top of the Hill with a space of $50 \mathrm{~m}$ between two transects. All the parasitized trees or not, as well as the parasitic plants were inventoried. A total of 120 host species distributed in 34 families and 75 genera were inventoried. Combretaceae and Mimosaceae were the most represented with 13 species each, either $10.83 \%$ for each family. Acacia was the most diverse with 10 species, either $8.33 \%$ of the host species. 18 genera, either $24 \%$ of the flora, were reported to be monospecific in this zone. In all of the 120 listed host species, 68 species or $56.66 \%$ of the host species were parasitized by 1 or 2 parasitic species and represent the first class (I) which is the class of not very sensitive host species parasitism of Loranthaceae. The second class (II) of susceptible host species was made up of 8 species, either $6.66 \%$ of the host species which represent species susceptible to parasitism. The third class (III) of host plants consists of species highly susceptible to parasitism. It was represented by 4 species, either $3.33 \%$ of the host species. Seven (7) species of Loranthaceae have been identified (Tapinanthus globiferus (A. Rich.) Danser, Tapinanthus ophiodes (Sprague) Danser, Tapinanthus belvisii (DC) Danser), Agelanthus dodoneifolius (DC) Polh. \& Wiens, Tapinanthus bangwensis (Engl. And Kr.) Danser, Phragmanthera capitata (Spreng) Ballé and Globimetula braunii (Engl.) Tiegh.) and divided into four genera which are Tapinanthus; Phragmanthera; Agelanthus and Globimetula. Tapinanthus was the most diverse with four species ( $T$. bangwensis, $T$. globiferus, T. ophiodes and T. dodoneifolius). Phragmanthera, Globimetula and Agelanthus each have one species. T. globiferus was the most represented (125.66 \pm 71.86 tufts / ha) and was more dense on the side West and at the top of the hills of the Mandara Mountains. Slopes and altitude influence the distribution of Loranthaceae over the Mounts.

Keywords: Loranthaceae, Parasite; Hemiparasite, Mandara Mountains, Far North, Cameroon.
\end{abstract}

Copyright () 2020 The Author(s): This is an open-access article distributed under the terms of the Creative Commons Attribution 4.0 International License (CC BY-NC 4.0) which permits unrestricted use, distribution, and reproduction in any medium for noncommercial use provided the original author and source are credited.

\section{INTRODUCTION}

Loranthaceae constitute a family of phanerogamous plants, chlorophyllian hemiparasites and epiphytes which, implanted on the aerial parts of their host plants [1], are responsible for economic, ecological and morphogenetic damage which varies according to the crops or woody species parasitized [24]. These parasitic plants are subdivided into two large groups, holoparasites which are devoid of chlorophyll, 
deriving from their hosts all their food and hemiparasites which take only water and mineral elements from the host while retaining their power of synthesis chlorophyllian. Loranthaceae are widely distributed around the world. They include around 77 genera and more than 950 species [5-8]. In Africa, Loranthaceae are very common and have caused extensive damage to natural formations and plantations in countries such as Burkina Faso, Cote d'Ivoire, Cameroon, Gabon, Ghana, Mali and many more Other African countries [4, 9, 10]. In Cameroon, the Loranthaceae are represented by nearly 26 species grouped into seven (07) genera. They lead to a huge drop in the yield of fruit species such as Dacryodes edulis and Cola nitida in the Littoral, East, South-West and West Regions [3, 11]. These woody parasitic plants are today a real scourge, given the damage they cause both in natural plant formations [3, 12] and in fruit plantations [11, 13]. Woody species of environmental and economic importance such as Azadirachta indica (Meliaceae), Balanites aegyptiaca (Balanitaceae), Terminalia mantaly (Combretaceae), Dalbergia sisso'o (Fabaceae), Acacia albida (Mimosaceae), Ficus sp. (Moraceae), Dacryodes edulis (Burseraceae) and fruit species of socio-economic importance such as Psidium guajava (Myrtaceae), Vitellaria paradoxa (Saposaceae), Persea americana (Lauraceae), are unfortunately attacked by Loranthaceae [14, 15, 3, 13]. Loranthaceae, although parasitic plants, are used internationally by traditional therapists and traditional healers in the treatment of various diseases such as cancer, hypertension, hypotension, diabetes, hepatitis, cerebral vascular accidents, infertility, microbial diseases and mental disturbances $[16,17,18,19]$. They are also used for mystical purposes. In Cameroon, very few studies have been carried out on Loranthaceae parasites of woody plants except for the work of Dibong et al. [15, 20,3] in the Littoral Region, de Azo'o et al. [13] in the Eastern Region, de Balle [21] in the Southern Region, and Ngotta et al. [14] in the South West Region, from Mapongmetsem et al. [22] and Ibrahima et al. [23] in the Adamawa Region. The purpose of this study is to identify the species of Loranthaceae parasitic in woody plants and to highlight their distribution according to altitude on the Mandara Mountains in the Far North, Cameroon.

\section{Material And Methods Study site}

The study was carried out in the SudanoSahelian zone of the Far North, Cameroon, located between $10^{\circ} 0$ 'and $12^{\circ} 0$ ' North latitude and between $14^{\circ} 0$ 'and $15^{\circ} 0^{\prime}$ East longitude ( Figure 1). Covering an area of $7660 \mathrm{~km}^{2}$, this area covers the Departments of Mayo Sava, Mayo Tsanaga, the district, Meri, Pette, Diamare and district of Mayo-Oulo in Mayo-Louti in the North, either $16.2 \%$ of the total area of the Far North Region. It forms a vast plain to the east and north and a set of mountain ranges called the Mandara Mountains in its western part along the Nigerian border, highly rugged with peaks reaching over $1200 \mathrm{~m}$ altitude. The climate is of the Sudano-Sahelian type, slightly milder and a single-mode rainfall, with two (2) seasons, a short rainy season, ranging from June to october and a long dry season, from November to may [16]. The annual average temperature is $28^{\circ} \mathrm{C}$ [24]. The soil is sandy-clayey and sandy. The plant formation is of the Sudano-Sahelian type characterized by the predominantly thorny shrub steppe and its extreme fragmentation due to natural conditions and human action. The main dominant species are Acacia albida, Ziziphus mauritiana, Tamarindus indica, Azadirachta indica, Acacia seyal, Diospyros mespiliformis, Dalbergia sisso'o. Some of these plants are used in traditional pharmacopoeia. The population of this Region was estimated at approximately 1,165,700 inhabitants in 2005 [25]. It is dominated by ethnic groups such as Mafa, Moufou, Hide, Foulbe (peuhl), Mabas and Woula. The main activities carried out are agriculture, commerce, animal husbandry and crafts. 


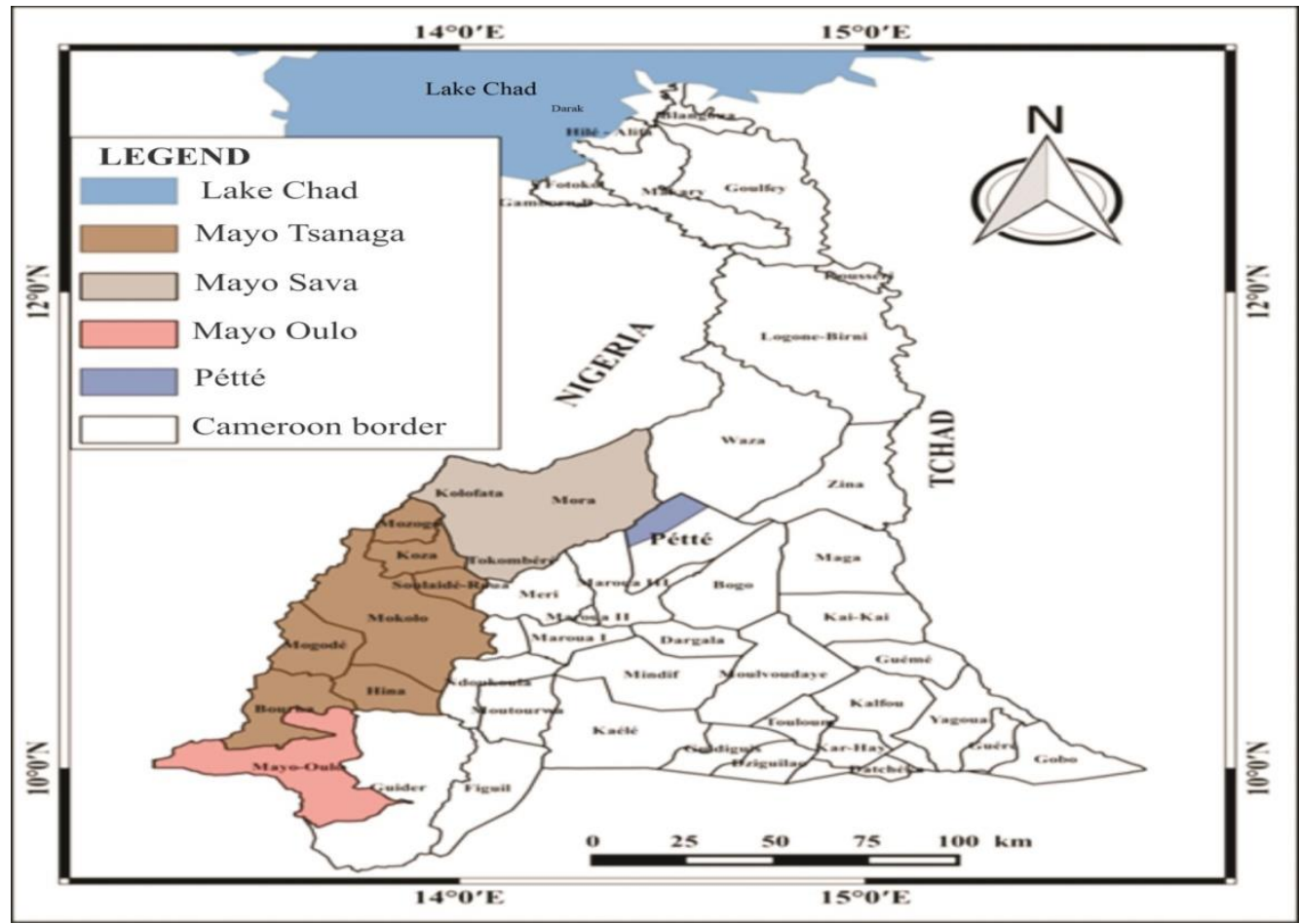

Figure 1: Location of the study area (Source: Bello Bienvenu, 2019)

\section{Collection of data}

The botanical inventory of woody plants as potential hosts of Loranthaceae was carried out to highlight the susceptibility of each woody species to the parasitism of Loranthaceae. Surveys were carried out to identify the feet of parasitized and non-parasitized host plants and to inventory the parasitic species per infested plant in the Mandara Mountains. We used the Trees, Shrubs and Lianas of the Drylands of West Africa [26] guide book to identify species in the field.

The pest inventory was also carried out in the Mandara Mountains area. It consisted in listing all the parasitic plants (Loranthaceae) encountered. All parasitic species were systematically harvested with their hosts, and species located at the crowns of large trees were observed using binoculars. The transect survey method was used for the floristic survey. The study took place in nine (09) Districts in four Departments of the Mandara Mountains. The inventory is carried out on 15 mountains chosen at the rate of one Mount every $10 \mathrm{~km}$ in all the massif of the Mandara Mountains; on each Mount, we have chosen two sides (east and west) and each side is subdivided into 16 altitudinal gradients. The experimental plan installed is therefore a split-plot $(15 \times 2)$ x 16 made up of 15 Mount (Altitude $\geq 1000 \mathrm{~m}$ ) representing the main treatment already developed by [36]. The two flanks (East and West) of each mountain constitute the secondary treatment and on each side, $50 \mathrm{~m} \times 20 \mathrm{~m}$ transects (repetitions) were installed by altitude level (tertiary treatment) starting with the plain, up to the top of the Mount with a space of $50 \mathrm{~m}$ between two transects. After data collection, the Mounts were grouped by three according to the altitude level of the plain of each
Mount to find five Mount (Mount $1(<500 \mathrm{~m}=$ Mount $1+$ Mount $2+$ Mount 15); Mount $2([500 \mathrm{~m}-600 \mathrm{~m}[=$ Mount $4+$ Mount $5+$ Mount 3) ; Mount 3 ([600 m $700 \mathrm{~m}$ [ $=$ Mount $6+$ Mount $7+$ Mount 13); Mount 4 ([700 m - $800 \mathrm{~m}$ [=Mount $8+$ Mount $9+$ Mount 14) ; Mount 5 (> $800 \mathrm{~m}=$ Mount $10+$ Mount $11+$ Mount 12)). On each Mount, three $50 \mathrm{~m}$ x $20 \mathrm{~m}$ transects are installed on sixteen (16) altitudinal gradients. The latter were also grouped by four to find four gradients (plain $(<500 \mathrm{~m})$; altitude 1 ([500 m - $700 \mathrm{~m} \mathrm{[)}$; altitude 2 ([700 m - $900 \mathrm{~m} \mathrm{[)}$; altitude 3 (> $900 \mathrm{~m})$ ). In each transect of each altitude level, all the woody species parasitized or not, the parasites and the tufts of Loranthaceae were counted. For each tree encountered, several parameters are noted; including the presence or absence of parasites and the name of the species or species of Loranthaceae present on the host plant. A sample (leaves, flowers, seeds) of each plant-parasite and its host is taken for identification purposes or for confirmation of identification made in the field.

\section{Data Analysis and Processing}

The collection of inventory data in the field made it possible to determine the species richness of Loranthaceae species. It is the number of Loranthaceae species found in the study area [8]. The data were classified by Mount, by flank and by altitude. The Excel 2016 spreadsheet was used to calculate the means and plot the histograms; the density was calculated according to the formula: $\mathrm{D}=\mathrm{N} / \mathrm{S}$ with $\mathrm{N}=$ number of individuals of the species of the study environment and $\mathrm{S}=$ area occupied by the species, the Shannon index is calculated according to the formula $\mathrm{H}^{\prime}=-\sum \mathrm{Pi} \ln \mathrm{Pi}$ with $\mathrm{H}^{\prime}=$ Shannon biodiversity index; $\mathrm{i}=\mathrm{a}$ middle 
species; $p$ (i) = Proportion of a species i compared to the total number of species (S) in the study environment (or specific diversity of the environment) which is calculated as follows: $\mathrm{p}(\mathrm{i})=\mathrm{ni} / \mathrm{N}$ where ni is the number of individuals of the species and $\mathrm{N}$ is the total number of individuals of all species [27]. From this index, we can derive the equitability of Pielou (E) which is given by the formula ISH / $\log 2$ N. Statgraphic 5.0 software is used to do analysis of variance (ANOVA) and Xlstat 2007 software is used to do principal component variable analysis and Duncan's test is used to compare the different Means. The Loranthaceae species determination keys used by Boussim [4] and by Houénon [8] are used to identify Loranthaceae.

\section{RESULTS}

Floristic composition and sensitivity of host plants In total, 120 host species distributed in 34 families and 75 genera are recorded on the Mandara Mountains (Table 1). Combretaceae and Mimosaceae are the most represented with 13 species each, either $10.83 \%$ for each family. They are followed by Caesalpiniaceae with 10 species or $8.33 \%$ and Moraceae with 9 species or $7.5 \%$. Acacia is the most diverse genus with 10 species, or $8.33 \%$ of the host species. It is followed by Combretum and Ficus with 9 species each, either $7.5 \%$ of the host plants for each genus. 18 genera or $24 \%$ are reported monospecific.
Three classes of host species are defined depending on the level of susceptibility to parasitism. In all of the 120 host species listed 68 species or $56.66 \%$ of the host species are parasitized by 1 or 2 parasitic species and represent the first class (I) which is the class of host species not very sensitive to the parasitism of Loranthaceae. Among these species, mention may be made of: Haematostaphis barteri, Lannea acida, Lannea fruticosa, Sclerocarya birrea, Annona senegalensis, Hexalobus monopetalus, Vernonia thomsoniana, Stereospermum kunthianum, Adansonia digitata, Boswellia dalzielii, Commiphora africana, Piliostigma thonningii, Piliostigma reticulatum, Capparis fascicularis, Boscia angustifolia. The second class (II) of susceptible host species is made up of 8 species, either $6.66 \%$ of the host species which represent species susceptible to the parasitism of Loranthaceae. Among these species are: Balanites aegyptiaca, Tamarindus indica, Boscia senegalensis, Anogeissus leiocarpus, Dalbergia sisso'o, Acacia seyal, Ziziphus abyssinica, Citrus limon. The third class (III) of host plants consists of species highly susceptible to parasitism by Loranthaceae. It is represented by 4 species, either $3.33 \%$ of the host species. These include Ziziphus mauritiana, Khaya senegalensis, Azadirachta indica and Diospyros mespiliformis, among others.

Regarding the Loranthaceae species, $T$. globiferus is much more represented with $41.67 \%$. It is followed by $A$. dodoneifolius with $38.47 \%$ and $T$. ophiodes with $12.50 \%$. The least parasitic parasite is $G$. braunii with $7.50 \%$.

Table 1: List of host species and their sensitity to Loranthaceae parasitism

\begin{tabular}{|c|c|c|c|c|c|c|c|c|c|}
\hline \multirow[b]{2}{*}{ Host plants } & \multicolumn{9}{|c|}{ Loranthaceae } \\
\hline & $\mathrm{AD}$ & TG & TO & TE & TB & $\mathrm{PC}$ & GB & Nep & SPS \\
\hline \multicolumn{10}{|l|}{ Anacardiaceae } \\
\hline Haematostaphis barteri Hook $\mathrm{f}$. & + & + & & & & & & 2 & vshp \\
\hline Lannea acida A. Rich.s.l. & & + & & & & & & 1 & vshp \\
\hline Lannea fructicosa (Hochst. ex A. Rich.) Engl. & & + & & & & & & 1 & vshp \\
\hline \multicolumn{10}{|l|}{ Lannea schimperi (Hochst. ex A. Rich.) Engl. } \\
\hline \multicolumn{10}{|l|}{ Lannea velunita A. Rich. } \\
\hline \multicolumn{10}{|l|}{ Mangifera indica $\mathrm{L}}$. \\
\hline Sclerocarya birrea (A. Rich.) Hochst. & & + & & & & & & 1 & vshp \\
\hline \multicolumn{10}{|l|}{ Annonaceae } \\
\hline Anona senegalenis Pers. & & & + & & & + & & 2 & vshp \\
\hline \multicolumn{10}{|l|}{ Anona squamosa L. } \\
\hline Hexalobus monopetalus (A. Rich.) Engl. \& Diels & + & + & & & & & & 2 & vshp \\
\hline \multicolumn{10}{|l|}{ Apiaceae } \\
\hline \multicolumn{10}{|l|}{ Steganotaenia araliacea Hochst. } \\
\hline \multicolumn{10}{|l|}{ Apocynaceae } \\
\hline \multicolumn{10}{|l|}{ Holarrhena floribunda (G. Don) Dur. \& Schinz } \\
\hline \multicolumn{10}{|l|}{ Asclepiadaceae } \\
\hline \multicolumn{10}{|l|}{ Calotropis procera (Ait.) Ait. f. } \\
\hline \multicolumn{10}{|l|}{ Asteraceae } \\
\hline Vernonia thomsoniana Oliv. \& Hiern & & + & & & & & & 1 & vshp \\
\hline \multicolumn{10}{|l|}{ Balanitaceae } \\
\hline Balanites aegyptiaca $(\mathrm{L}$.$) Del.$ & + & + & & & + & & & 3 & shp \\
\hline \multicolumn{10}{|l|}{ Bignoniaceae } \\
\hline Stereospermum kunthianum Cham. & & + & & & & & & 1 & vshp \\
\hline \multicolumn{10}{|l|}{ Bombacaceae } \\
\hline Adansonia digitata $\mathrm{L}$. & & + & & & & & & 1 & vshp \\
\hline
\end{tabular}




\begin{tabular}{|c|c|c|c|c|c|c|c|c|c|}
\hline Ceiba pentandra (L.) Gaertn. & & & & & & & & & \\
\hline \multicolumn{10}{|l|}{ Burseraceae } \\
\hline Boswellia dalzielii Hutch. & & + & & + & & & & 2 & vshp \\
\hline \multicolumn{10}{|l|}{ Boswellia papyrifera (Del.) A. Rich. } \\
\hline Commiphora africana (A. Rich.) Engl. & & & & & & & + & 1 & vshp \\
\hline \multicolumn{10}{|l|}{ Commiphora kerstingii Engl. } \\
\hline \multicolumn{10}{|l|}{ Caesalpiniaceae } \\
\hline Bauhinia rufencens Lam. & + & + & & & & & & 2 & vshp \\
\hline \multicolumn{10}{|l|}{ Afzelia africana Smith ex Pers. } \\
\hline Daniellia oliveri (Rolfe) Hutch. \& Dalz. & & & & + & & & & 1 & vshp \\
\hline \multicolumn{10}{|l|}{ Isoberlinia doka Craib \& Stapf } \\
\hline Piliostigma reticulatum (DC.) Hochst. & + & + & & & & & & 2 & vshp \\
\hline Piliostigma thonningii (Schum.) Milne-Redh. & & + & & & & & & 1 & vshp \\
\hline \multicolumn{10}{|l|}{ Pterocarpus erinaceus Poir. } \\
\hline \multicolumn{10}{|l|}{ Senna siamea Lam. } \\
\hline \multicolumn{10}{|l|}{ Senna singueana (Del.) Lock } \\
\hline Tamarindus indica $\mathrm{L}$. & + & + & + & + & & & & 4 & $\operatorname{shp}$ \\
\hline \multicolumn{10}{|l|}{ Capparaceae } \\
\hline Capparis fascicularis DC. & & + & & & + & & & 2 & vshp \\
\hline Boscia angustifolia A. Rich. & & + & & & & & & 1 & vshp \\
\hline Boscia senegalensis (Pers.) Lam. ex Poir. & + & + & + & & & & & 3 & $\operatorname{shp}$ \\
\hline Cadaba farinosa Forssk. & & & & & & + & & 1 & vshp \\
\hline Capparis sepiaria $\mathrm{L}$. & & & & & & + & & 1 & vshp \\
\hline \multicolumn{10}{|l|}{ Maerua angolensis DC. } \\
\hline \multicolumn{10}{|l|}{ Celastraceae } \\
\hline Maytenus senegalensis (Lam.) Exell. & & + & & & & & & 1 & vshp \\
\hline \multicolumn{10}{|l|}{ Combretaceae } \\
\hline Anogeissus leiocarpus (DC.) Guill. \& Perr. & + & + & & & & & + & 3 & $\operatorname{shp}$ \\
\hline Combretum aculeatum Vent. & & & & & & & & & \\
\hline Combretum adenogonium Steud. ex. A. Rich. & & & & & & & + & 1 & vshp \\
\hline Combretum collinum Fresen. & & & & & & & & & \\
\hline Combretum glutinosum Perr. ex DC. & + & & & & & & + & 2 & vshp \\
\hline Combretum lecardii Engl. \& Diels & & & & & + & + & & 2 & vshp \\
\hline Combretum micranthum G. Don & & & + & & & & & 1 & vshp \\
\hline Combretum molle R. Br. ex G. Don & & & & & & & & & \\
\hline Combretum nigricans Lepr. ex Guill. et Perr. & & & + & & + & & & 2 & vshp \\
\hline Combretum nioroense Aubrév. ex Keay & & & & & & & & & \\
\hline Guiera senegalensis J.F. Gmel. & + & + & & & & & & 2 & vshp \\
\hline Terminalia glauscesens Hochst. & & + & + & & & & & 2 & vshp \\
\hline Terminalia macroptera Guill. \& Perr. & & + & & & & & & 1 & vshp \\
\hline Terminalia mantaly H. Perr. & & & & & & & & & \\
\hline Ebenaceae & & & & & & & & & \\
\hline Diospyros mespiliformis Hochst. ex A. Rich. & + & + & + & + & + & & & 5 & hshp \\
\hline Euphorbiaceae & & & & & & & & & \\
\hline Croton macrostachyus Hochst. ex Del. & & + & & & & & & 1 & vshp \\
\hline Croton psedopulchellus $\mathrm{Pax}$ & & + & & & & & & 1 & vshp \\
\hline Euphorbia kamerunica $\mathrm{Pax}$ & + & + & & & & & & 2 & vshp \\
\hline Flueggea virosa (Roxb. ex Willd.) Voigt & & & & & & & & & \\
\hline Jatropha gossypiifolia L. & & + & + & & & & & 2 & vshp \\
\hline Phyllanthus muellerianus (O. Ktze) Exell & + & & & & & & & 1 & vshp \\
\hline Uapaca togoensis $\mathrm{Pax}$ & & & & & & & + & 1 & vshp \\
\hline Fabaceae & & & & & & & & & \\
\hline Andira inermis (Wright) DC. & & & & & & & & & \\
\hline Dalbergia boehmii Taub. & + & + & & & & & & 2 & vshp \\
\hline Dalbergia melanoxylon Guill. \& Perr. & + & & & & & & & 1 & vshp \\
\hline Dalbergia sissoo Roxb. & + & + & & & + & & & 3 & $\operatorname{shp}$ \\
\hline Dicrostachys cinera (L.) Wight \& Arn. & & & & & & + & + & 2 & vshp \\
\hline Entada africana Guill. \& Perr. & & & & & & & + & 1 & vshp \\
\hline Pterocarpus erinaseus Poir. & + & & & & & & & 1 & vshp \\
\hline Pterocarpus lucens Guill. \& Perr. & + & & & & & & & 1 & vshp \\
\hline Flacourtiaceae & & & & & & & & & \\
\hline Flacourtia indica Willd. & & + & & & & & & 1 & vshp \\
\hline Loganiaceae & & & & & & & & & \\
\hline
\end{tabular}




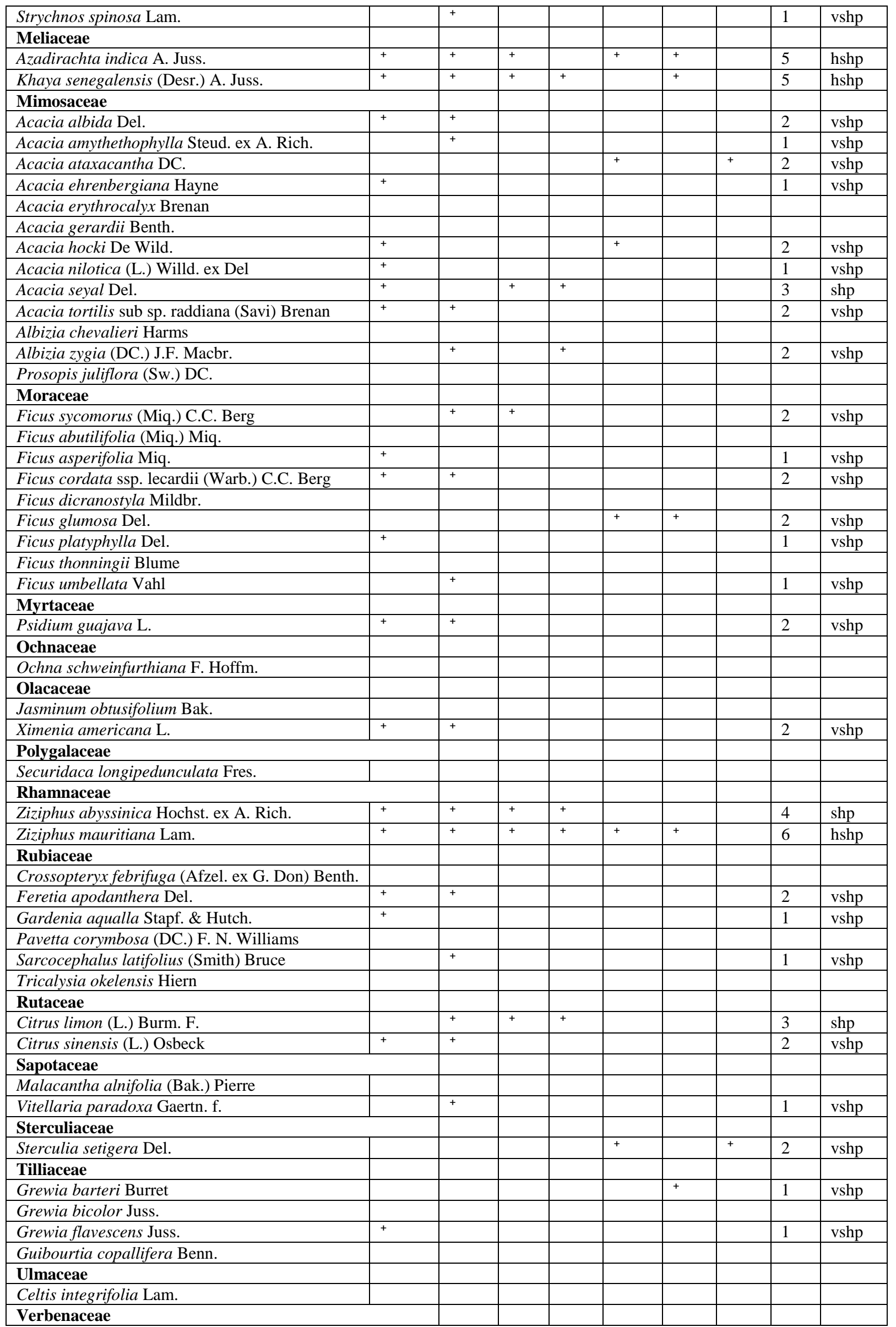




\begin{tabular}{|l|l|l|l|l|l|l|l|l|l|}
\hline Lippia chevalieri Moldenke & & & & & & & & & \\
\hline Vitex doniana Sweet. & + & + & & & & & & 2 & vshp \\
\hline Vitex madiensis Oliv. & & + & & & + & & & 2 & vshp \\
\hline SeP $(\%)$ & 31.67 & 41.67 & 12.5 & 8.33 & 10.83 & 8.33 & 7.5 & & \\
\hline
\end{tabular}

AD: Agelanthus dodoneifolius, TG: Tapinanthus globiferus, TO: Tapinanthus ophiodes, TB.: Tapinanthus bangwensis, TE: Tapinanthus belvisii, PC: Phragmanthera capitata, GB: Globimetula braunii ; SPS: Specificity of parasitic species; Npshp: number of parasitic species per host plant; pshp: parasitic sensitivity of the host plant (1 to 2 parasites $=$ not very sensitive host plant (vshp), 3 to 4 parasites $=$ sensitive host plant (shp), 5 to 6 parasites $=$ highly sensitive host plant (hshp); +: presence.

\section{Taxonomic composition of Loranthaceae}

In total, seven (7) species of Loranthaceae have been recorded on the Mandara Mountains (Table 2). Tapinanthus globiferus (A. Rich.) Danser is the most represented with an average density of $125.66 \pm$ 71.86 tufts / ha. It is followed by Agelanthus dodoneifolius (DC) Polh. \& Wiens with an average density of $116.39 \pm 53.74$ tufts / ha. Then it is Tapinanthus ophiodes (Sprague) Danser which comes with an average density of $92.65 \pm 51.06$ tufts / ha; Tapinanthus belvisii (DC) Danser has an average density of $70.24 \pm 53.63$ tufts / ha; Phragmanthera capitata (Spreng) Ballé has an average density of 57.74 \pm 27.2 tufts / ha. Tapinanthus bangwensis (Engl. And Kr.) Danser has an average density of $51.4 \pm 33.24$ tufts / ha. Globimetula braunii (Engl.) Tiegh. is the least represented parasitic species on the Hills with an average density of $45.57 \pm 19.01$ tufts / ha. The specific richness of Loranthaceae species varies between 1 and 3 parasitic species per host plant. Variance analysis shows that there is a highly significant difference between Loranthaceae species $(\mathrm{P}<0.001)$.

Table 2: Taxonomic diversity of Loranthaceae

\begin{tabular}{|l|l|c|}
\hline Kind & \multicolumn{1}{|c|}{ Species } & Density \\
\hline Agelanthus & Agelanthus dodoneifolius & $59.69 \pm 34.91^{\mathrm{e}}$ \\
\hline \multirow{4}{*}{ Tapinanthus } & Tapinanthus globiferus & $73.38 \pm 37.48^{\mathrm{f}}$ \\
\cline { 2 - 3 } & Tapinanthus ophiodes & $44.35 \pm 42.8^{\mathrm{d}}$ \\
\cline { 2 - 3 } & Tapinanthus bangwensis & $25.22 \pm 36.87^{\mathrm{b}}$ \\
\cline { 2 - 3 } & Tapinanthus belvisii & $35.01 \pm 17.77^{\mathrm{c}}$ \\
\hline Phragmanthera & Phragmanthera capitata & $26.96 \pm 21.89^{\mathrm{b}}$ \\
\hline Globimetula & Globimetula braunii & $17.26 \pm 29.36^{\mathrm{a}}$ \\
\hline Average/ Standard deviation & $40.27 \pm 31.58$ \\
\hline \multicolumn{2}{|l}{ Values assigned the same letters in superscript do not show significant statistical differences }
\end{tabular}

Loranthaceae species are unevenly dispersed over the Hills. T. globiferus, A. dodoneifolius and T. ophiodes are respectively the most represented in the study area (Figure 2). These dispersed species are the densest, that is to say the species for which we are more likely to encounter them on all the mountains in the study area. The other species which are less represented form clouds around the two (axes f1 and f2: 99.91\%). These species represented in the form of a cloud are less dense and are less common in the study area.

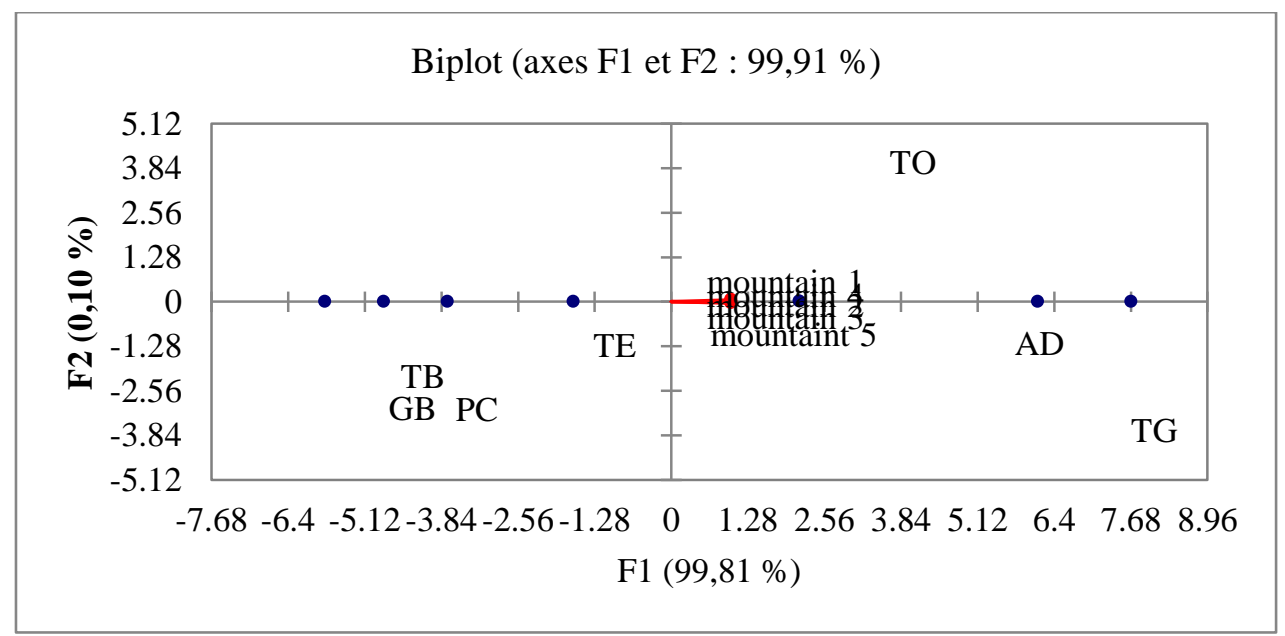

Figure 2: Dispersion of species on the Mountains

AD: Agelanthus dodoneifolius, TG: Tapinanthus globiferus, TO: Tapinanthus ophiodes, TB: Tapinanthus bangwensis, TE: Tapinanthus belvisii, PC: Phragmanthera capitata, GB: Globimetula braunii 


\section{Density of Loranthaceae on the Mountains}

Table 3 shows the density on the two sides of the Mandara Mountains. Between the two sides, the density of parasitic species is higher on the East side $(82.07 \pm 61.68$ tufts / ha) than on the West side (77.83 \pm 49.62 tufts / ha). Between the Loranthaceae, on the East flank, T. globiferus is more abundant $(150.11 \pm 125.69$ tufts / ha). It is followed by A. dodoneifolius so the average density is $120.24 \pm 136.19$ tufts / ha and $T$. ophiodes with an average density of $92.58 \pm 104.9$ tufts / ha; T. belvisii (71.78 \pm 71.8 tufts / ha); $P$. capitata (56.19 \pm 50.87 tufts / ha); T. bangwensis (48.44 \pm 27.92 tufts / ha). On this slope, the least represented species is $G$. braunii with an average density of $35.14 \pm 126.43$ tufts / ha.
On the West side, T. globiferus has a higher density (143.42 \pm 82.3 tufts / ha) but below the density on the East side. A. dodoneifolius comes next with an average density of $114.5 \pm 87.3$ tufts / ha; followed by T. ophiodes $(82.03 \pm 29.45$ tufts / ha); T. belvisii $(68.28$ \pm 70.94 tufts / ha); P. capitata (51.64 \pm 40.54 tufts / ha); T. bangwensis $(51.03 \pm 56.87$ tufts / ha) and G. braunii is less represented on this slope with an average density of $33.92 \pm 99.23$ tufts / ha. The analysis of variance (ANOVA) indicates that there is no difference between the two sides $(\mathrm{P}>0.05)$ while between the parasitic species the difference is highly significant $(\mathrm{P}<0.001)$.

Table 3: Density of Loranthaceae on the Mounts

\begin{tabular}{|c|c|c|c|c|c|c|}
\hline Species & M 1 & M 2 & M 3 & M 4 & M 5 & average/SD \\
\hline TD & 347.71 & 343.96 & 347.71 & 347.71 & 358.75 & $349.17 \pm 5.6$ \\
\hline TG & 378.33 & 365.00 & 376.46 & 385.42 & 379.69 & $376.98 \pm 7.49$ \\
\hline TO & 278.33 & 286.88 & 276.04 & 273.13 & 275.42 & $277.96 \pm 5.32$ \\
\hline TB & 152.92 & 153.33 & 155.00 & 150.21 & 159.58 & $154.21 \pm 3.46$ \\
\hline TE & 201.04 & 211.98 & 215.31 & 213.44 & 211.77 & $210.71 \pm 5.59$ \\
\hline PC & 173.75 & 172.50 & 171.35 & 177.81 & 170.63 & $173.21 \pm 2.83$ \\
\hline GB & 135.21 & 136.98 & 134.38 & 137.60 & 139.38 & $136.71 \pm 1.98$ \\
\hline average/SD & $238.18 \pm 97.17$ & $238.66 \pm 93.17$ & $239.46 \pm 95.94$ & $240.76 \pm 97.43$ & $242.17 \pm 97.5$ & $239.85 \pm 96.15$ \\
\hline
\end{tabular}

M $1=$ Mount $1(<500 \mathrm{~m}=\mathrm{M} 1+\mathrm{M} 2+\mathrm{M} 15) ; \mathrm{M} 2=$ Mount $2([500 \mathrm{~m}-600 \mathrm{~m}[=\mathrm{M} 4+\mathrm{M} 5+\mathrm{M} 3) ; \mathrm{M} 3=\mathrm{Mount} 3([600 \mathrm{~m}-$ $700 \mathrm{~m}[=\mathrm{M} 6+\mathrm{M} 7+\mathrm{M} 13) ; \mathrm{M} 4=$ Mount $4([700 \mathrm{~m}-800 \mathrm{~m}[=\mathrm{M} 8+\mathrm{M} 9+\mathrm{M} 14) ; \mathrm{M} 5=$ Mount $5(>800 \mathrm{~m}=\mathrm{M} 10+\mathrm{M} 11+\mathrm{M}$ 12); SD: Standard deviation ; AD: Agelanthus dodoneifolius, TG: Tapinanthus globiferus, TO: Tapinanthus ophiodes, TB: Tapinanthus bangwensis, TE: Tapinanthus belvisii, PC: Phragmanthera capitata, GB: Globimetula braunii

On the same lines on the one hand and the same columns on the other hand, the values assigned the same superscript letters do not show statistically significant differences.

The analysis of the principal component variables (PCA) shows that the five (05). Mounts are positively correlated with each other. Figure 3 shows the correlation between the different Mounts. The correlation is very strong (Pearson, $r=0.987$ ) between Mount 3 and Mount 4, between Mount 3 and Mount 5 (0.986) and between Mount 1 and Mount 2 (Pearson,r=0.942).

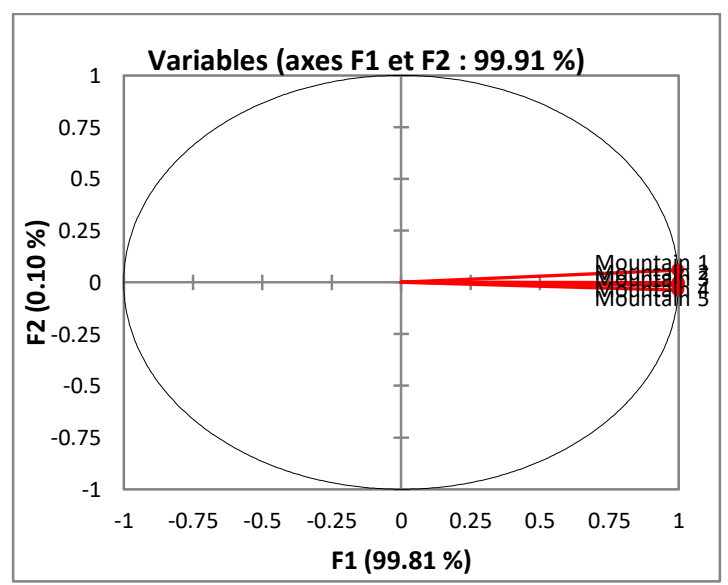

Figure 3: Correlation between the Mounts 


\section{Loranthaceae density on the slopes}

Table 4 shows the density on the two sides of the Mandara Mountains. Between the two sides, the density of parasitic species is higher on the East side $(82.07 \pm 61.68$ tufts / ha) than on the West side (77.83 \pm 49.62 tufts / ha). Between the Loranthaceae, on the East flank, T. globiferus is more abundant $(150.11 \pm 125.69$ tufts / ha). It is followed by A. dodoneifolius so the average density is $120.24 \pm 136.19$ tufts / ha and $T$. ophiodes with an average density of $92.58 \pm 104.9$ tufts / ha ; T. belvisii $(71.78 \pm 71.8$ tufts / ha $) ; P$. capitata $(56.19 \pm 50.87$ tufts / ha) ; T. bangwensis (48.44 \pm 27.92 tufts / ha). On this slope, the least represented species is $G$. braunii with an average density of $35.14 \pm$ 126.43 tufts / ha.
On the West side, T. globiferus has a higher density (143.42 \pm 82.3 tufts / ha) but below the density on the East side. A. dodoneifolius comes next with an average density of $114.5 \pm 87.3$ tufts / ha; followed by T. ophiodes $(82.03 \pm 29.45$ tufts / ha) $;$ T. belvisii $(68.28$ \pm 70.94 tufts / ha) $; P$. capitata $(51.64 \pm 40.54$ tufts / ha $)$ ; T. bangwensis $(51.03 \pm 56.87$ tufts / ha) and $G$. braunii is less represented on this slope with an average density of $33.92 \pm 99.23$ tufts / ha. The analysis of variance (ANOVA) indicates that there is no difference between the two sides $(\mathrm{P}=0.395>0.05)$ while between the parasitic species the difference is highly significant $(\mathrm{P}<0.001)$

Table 4: density of Loranthaceae species on the slopes

\begin{tabular}{|c|c|c|c|}
\hline & & East side & West side \\
\hline Kinds & Species & Density & Density \\
\hline Agelanthus & Agelanthus dodoneifolius & $120.24 \pm 136.19^{\mathrm{e}}$ & $114.5 \pm 87.3^{\mathrm{e}}$ \\
\hline \multirow{4}{*}{ Tapinanthus } & Tapinanthus globiferus & $150.11 \pm 125.69^{f}$ & $143.42 \pm 82.3^{\mathrm{f}}$ \\
\hline & Tapinanthus ophiodes & $92.58 \pm 104.9^{\mathrm{d}}$ & $82.03 \pm 29.45^{\mathrm{d}}$ \\
\hline & Tapinanthus bangwensis & $48.44 \pm 27.92^{b}$ & $51.03 \pm 56.87^{b}$ \\
\hline & Tapinanthus belvisii & $71.78 \pm 71.8^{\mathrm{c}}$ & $68.28 \pm 70.94^{\mathrm{c}}$ \\
\hline Phragmanthera & Phragmanthera capitata & $56.19 \pm 50.87^{\mathrm{b}}$ & $51.64 \pm 40.54^{\mathrm{b}}$ \\
\hline Globimetula & Globimetula braunii & $35.14 \pm 126.43^{\mathrm{a}}$ & $33.92 \pm 99.23^{\mathrm{a}}$ \\
\hline \multicolumn{2}{|c|}{ Average/ Standard deviation } & $82.07 \pm 61.68^{\mathrm{a}}$ & $77.83 \pm 49.62^{\mathrm{a}}$ \\
\hline
\end{tabular}

On the same column, the values assigned the same letters in superscript do not show significant statistical differences

\section{Loranthaceae density according to the altitudinal gradient}

The density of Loranthaceae species varies between the plain and the Mount but also between the different altitude levels of the Mount ranging from the bottom (A 1) to the top (A 3). Between the different height differences, the summit of the Mount (A 3) has a higher density $(25.02 \pm 12.65$ tufts / ha) compared to the other altitude levels. It precedes the middle of the Mounts (A 2) which has an average density of $21.83 \pm$ 10.69 tufts / ha ; the bottom (A1) therefore the average density is $18.19 \pm 9.83$ tufts / ha and the plain (A 0) is the least dense zone in individuals $(14.9 \pm 8.87$ tufts / ha). The average density of Loranthaceae species increases as one moves from the plain (A 0) to the top of the Hills (A 3). At the species level, the density of six species increases from bottom to top. These are $A$. dodoneifolius, T. globiferus, T. ophiodes, T. belvisii, $P$. capitata and G. braunii. On the other hand, the average density of $T$. bangwensis decreases as one goes from the plain (A 0) to the top of the Hills. This species rather prefers the plain than the summit of the Mounts compared to the other species which, they rather prefer the summit. The analysis of variance (ANOVA) states that there is a highly significant difference between the altitude levels $(\mathrm{P}<0.001)$.

Table 5: Density of Loranthaceae species on altitudinal gradients

\begin{tabular}{|c|c|c|c|c|c|}
\hline Species & A 0 & A 1 & A 2 & A 3 & Average/SD \\
\hline TD & 21.15 & 26.65 & 33.19 & 38.38 & $29.84 \pm 7.52$ \\
\hline TG & 28.75 & 33.22 & 38.73 & 44.75 & $36.36 \pm 6.92$ \\
\hline TO & 17.07 & 21.57 & 23.14 & 26.22 & $22 \pm 3.81$ \\
\hline TB & 15.72 & 14.44 & 10.81 & 8.76 & $12.43 \pm 3.21$ \\
\hline TE & 11.36 & 16.13 & 20.00 & 22.54 & $17.51 \pm 4.87$ \\
\hline PC & 9.15 & 11.64 & 14.96 & 16.78 & $13.13 \pm 3.4$ \\
\hline GB & 1.11 & 3.71 & 11.99 & 17.72 & $8.63 \pm 7.63$ \\
\hline Average/SD & $14.9 \pm 8.87$ & $18.19 \pm 9.83$ & $21.83 \pm 10.69$ & $25.02 \pm 12.65$ & $19.99 \pm 10.07$ \\
\hline
\end{tabular}

A $0=$ plain $(<500 \mathrm{~m}) ;$ A 1 = Altitude 1 ([500 m - $700 \mathrm{~m} \mathrm{[)}$; A 2 = Altitude $2([700 \mathrm{~m}-900 \mathrm{~m} \mathrm{[}) ; \mathrm{A} 3$ = Altitude 3 (> $900 \mathrm{~m}) ; \mathrm{SD}$ : Standard deviation ; AD : Agelanthus dodoneifolius, TG: Tapinanthus globiferus, TO: Tapinanthus ophiodes, TB: Tapinanthus bangwensis, TE: Tapinanthus belvisii, PC: Phragmanthera capitata, GB: Globimetula braunii . 
On the same lines on the one hand and the same columns on the other hand, the values assigned the same superscript letters do not show statistically significant differences.

\section{Density of Loranthaceae interaction between Mounts and Slopes}

The density of the two sides of each Mount varies from one Mount to another (table 6). Mount 5 is denser with an average density of $142.03 \pm 3.87$ tufts / ha for both sides. It is followed by Mount 4 which has an average density of $131.24 \pm 4.36$ tufts / ha for the two slopes; Mount $3(120.67 \pm 5.53$ tufts / ha) for the two slopes; Mount 2 (114.16 \pm 5.62 tufts / ha) combining the two sides and Mount 1 has the lowest density for the two sides $(95.92 \pm 5.09$ tufts / ha $)$. The analysis of variance shows that the difference is very significant between the different Mounts $(\mathrm{P}=0.004)$. Between the two sides of each Mount, ANOVA does not report any significant difference $(P>0.05)$.

Table 6: density of Loranthaceae species of the interaction between the Mounts and the Slopes

\begin{tabular}{|c|c|c|c|c|c|c|c|c|c|c|}
\hline \multirow[b]{2}{*}{ Species } & \multicolumn{2}{|c|}{ M 1} & \multicolumn{2}{|c|}{ M 2} & \multicolumn{2}{|c|}{ M 3} & \multicolumn{2}{|l|}{ M 4} & \multicolumn{2}{|c|}{ M 5} \\
\hline & $\begin{array}{l}\text { East } \\
\text { side }\end{array}$ & $\begin{array}{l}\text { West } \\
\text { side }\end{array}$ & East side & $\begin{array}{l}\text { West } \\
\text { side }\end{array}$ & East side & $\begin{array}{l}\text { West } \\
\text { side }\end{array}$ & East side & $\begin{array}{l}\text { West } \\
\text { side }\end{array}$ & East side & $\begin{array}{l}\text { West } \\
\text { side }\end{array}$ \\
\hline TD & 154.38 & 146.46 & 175.42 & 159.17 & 183.75 & 179.58 & 191.04 & 183.75 & 216.88 & 200.21 \\
\hline $\mathrm{TG}$ & 192.08 & 185.21 & 222.29 & 209.79 & 216.88 & 206.46 & 239.79 & 227.71 & 254.79 & 246.46 \\
\hline TO & 116.67 & 109.58 & 107.71 & 100.00 & 140.42 & 122.08 & 156.46 & 135.42 & 183.54 & 158.54 \\
\hline TB & 38.96 & 36.46 & 78.54 & 75.00 & 79.58 & 75.63 & 100.63 & 97.50 & 76.04 & 98.13 \\
\hline $\mathrm{TE}$ & 107.71 & 96.46 & 96.04 & 87.29 & 99.79 & 97.29 & 116.04 & 114.58 & 118.75 & 116.46 \\
\hline $\mathrm{PC}$ & 61.25 & 52.08 & 89.38 & 78.96 & 94.79 & 84.79 & 90.83 & 83.75 & 85.21 & 87.71 \\
\hline GB & 25.63 & 20.00 & 57.50 & 61.04 & 56.88 & 51.46 & 45.42 & 54.38 & 78.13 & 67.50 \\
\hline \multirow[t]{2}{*}{ Average/SD } & $\begin{array}{l}99.52 \\
\pm 56.73^{\mathrm{a}}\end{array}$ & $\begin{array}{l}92.32 \\
\pm 55.86^{\mathrm{a}}\end{array}$ & $\begin{array}{l}118.13 \\
\pm 58.88^{\mathrm{b}}\end{array}$ & $\begin{array}{l}110.18 \\
\pm 54.12^{\mathrm{b}}\end{array}$ & $\begin{array}{l}124.58 \\
\pm 58.28^{\mathrm{c}}\end{array}$ & $\begin{array}{l}116.76 \\
\pm 56.83^{\mathrm{c}}\end{array}$ & $\begin{array}{l}134.32 \\
\pm 65.95^{\mathrm{d}}\end{array}$ & $\begin{array}{l}128.15 \\
\pm 59.99^{d}\end{array}$ & $\begin{array}{l}144.76 \\
\pm 73.25^{\mathrm{e}}\end{array}$ & $\begin{array}{l}139.29 \\
\pm 65.32^{\mathrm{e}}\end{array}$ \\
\hline & \multicolumn{2}{|c|}{$95.92 \pm 5.09^{\mathrm{a}}$} & \multicolumn{2}{|c|}{$114.16 \pm 5.62^{\mathrm{ab}}$} & \multicolumn{2}{|c|}{$120.67 \pm 5.53^{\mathrm{abc}}$} & \multicolumn{2}{|c|}{$131.24 \pm 4.36^{\mathrm{bc}}$} & \multicolumn{2}{|c|}{$142.03 \pm 3.87^{\mathrm{c}}$} \\
\hline
\end{tabular}

Mount $1(<500 \mathrm{~m}=\mathrm{M} 1+\mathrm{M} 2+\mathrm{M} 15) ;$ Mount $2([500 \mathrm{~m}-600 \mathrm{~m} \mathrm{[=} \mathrm{M} \mathrm{4} \mathrm{+} \mathrm{M} \mathrm{5} \mathrm{+} \mathrm{M} \mathrm{3);} \mathrm{Mount} 3([600 \mathrm{~m}-700 \mathrm{~m} \mathrm{[=}$ M 6 + M 7 + M 13); Mount 4 ([700 m - 800 m [= M $8+$ M 9 + M 14); Mount 5 (> 800 m = M $10+$ M $11+$ M 12); SD: Standard deviation ; TD: Agelanthus dodoneifolius ; TG: Tapinanthus globiferus ; TO: Tapinanthus ophiodes ; TB: Tapinanthus bangwensis ; TE: Tapinanthus belvisii ; PC: Phragmanthera capitata ; GB: Globimetula braunii

On the same lines, values assigned the same superscript letters do not show statistically significant differences.

\section{Density of Loranthaceae of interaction between slopes and altitudes}

For the four altitude levels combined, the mean density of Loranthaceae species varies from species to species (Table 7). T. globiferus shows a higher density of $899.38 \pm 19.01$ stufts / ha. It is followed by $A$. dodoneifolius $(842.77 \pm 19.23$ tufts / ha). T. ophiodes occupies the third position with a density of $784.44 \pm$
19.64 tufts / ha. A density of $575 \pm 15.12$ tufts / ha is then recorded by $T$. bangwensis. The latter is followed by $T$. belvisii which obtains a density of $556.12 \pm 5.26$ tufts / ha. A relatively low density of $440.56 \pm 7.5$ tufts / ha is observed by $P$. capitata and the lowest density $(378.89 \pm 6.99$ tufts / ha) is obtained by G. braunii. For the difference between species, the analysis of variance (ANOVA) specifies a highly significant difference $(\mathrm{P}<$ $0.001)$.

Table 7: density of Loranthaceae species on the slopes with the four levels of altitude

\begin{tabular}{|c|c|c|c|c|c|c|c|c|c|}
\hline \multirow[b]{2}{*}{ Species } & \multicolumn{4}{|c|}{ East } & \multicolumn{4}{|c|}{ West } & \multirow[b]{2}{*}{ Average/SD } \\
\hline & A 0 & A 1 & A 2 & A 3 & $\mathrm{~A} 0$ & A 1 & A 2 & A 3 & \\
\hline $\mathrm{AD}$ & 118.00 & 121.00 & 123.00 & 129.28 & 86.50 & 82.72 & 87.44 & 94.83 & $842.77 \pm 19.23^{\mathrm{e}}$ \\
\hline TG & 124.67 & 126.78 & 127.72 & 138.44 & 94.83 & 88.44 & 95.33 & 103.17 & $899.38 \pm 19.01^{f}$ \\
\hline $\mathrm{TO}$ & 105.78 & 115.44 & 115.22 & 124.83 & 75.39 & 75.50 & 83.00 & 89.28 & $784.44 \pm 19.64^{d}$ \\
\hline TB & 86.89 & 82.11 & 77.44 & 92.61 & 50.39 & 57.72 & 60.78 & 67.06 & $575 \pm 15.12^{\mathrm{c}}$ \\
\hline TE & 64.11 & 65.44 & 71.89 & 77.06 & 67.06 & 63.28 & 71.89 & 75.39 & $556.12 \pm 5.26^{\mathrm{c}}$ \\
\hline $\mathrm{PC}$ & 55.22 & 54.33 & 55.22 & 65.39 & 42.06 & 49.39 & 54.67 & 64.28 & $440.56 \pm 7.5^{b}$ \\
\hline GB & 41.89 & 48.78 & 49.67 & 55.94 & 33.72 & 45.50 & 50.22 & 53.17 & $378.89 \pm 6.99^{\mathrm{a}}$ \\
\hline
\end{tabular}

A0 = plain $(<500 \mathrm{~m}) ;$ A $1=$ Altitude 1 ([500 m -700 m [); A 2 = Altitude 2 ([700 m - $900 \mathrm{~m} \mathrm{[);A} 3$ = Altitude 3 (> $900 \mathrm{~m}) ; \mathrm{SD}$ : Standard deviation AD: Agelanthus dodoneifolius ; TG: Tapinanthus globiferus ; TO: Tapinanthus ophiodes ; TB: Tapinanthus bangwensis ; TE: Tapinanthus belvisii ; PC: Phragmanthera capitata ; GB: Globimetula braunii

Values assigned the same letters in superscript do not show statistically significant differences. 


\section{Relative frequency of distribution of Loranthaceae} species

The number of species of Loranthaceae parasitic on ligneous plants does not vary from one slope to another $(\mathrm{P}=0.597)$. All 7 species of parasitic plants are present on the two slopes (Table 8). The parasitic flora common to both sides is made up of all seven species (A. dodoneifolius, T. globiferus, T. ophiodes, $P$. capitata, T. bangwensis, T. belvisii and $G$. braunii). In sides, A. dodoneifolius and T. globiferus are the most frequent species with a frequency of $100 \%$ in both sides. T. ophiodes is more frequent on the East side $(93.33 \%)$ than on the West side $(86.66 \%)$. As for $T$. bangwensis, it has the same frequency of occurrence on both flanks $(80 \%)$. T. belvisii is much more present on the West side $(93.33 \%)$ than on the East side $(86.66 \%)$. P. capitata and G. braunii are more frequent on the East side with respectively $66.66 \%$ and $40 \%$ than on the West side (40\% and $26.66 \%$ respectively). In terms of species presence, there is no significant difference between the two sides. Depending on the frequency of presence, the analysis of variance (ANOVA) shows no very significant difference between the two sides $(\mathrm{P}$ > $0.05)$. In terms of the frequency of species on the slopes, the analysis of variance (ANOVA) states a highly significant difference $(\mathrm{P}<0.001)$.

Table 8: Frequencies of presence of Loranthaceae species on the east and west slopes

\begin{tabular}{|l|c|c|}
\hline \multirow{2}{*}{ Species } & \multicolumn{2}{|c|}{ Relative frequency of presence of species (\%) } \\
\cline { 2 - 3 } & East side & West side \\
\hline AD & $100^{\mathrm{e}}$ & $100 \mathrm{a}$ \\
\hline TG & $100^{\mathrm{e}}$ & $100 \mathrm{a}$ \\
\hline TO & $93.33^{\mathrm{d}}$ & $86.66 \mathrm{c}$ \\
\hline TB & $80^{\mathrm{c}}$ & $80 \mathrm{c}$ \\
\hline TE & $86.66^{\mathrm{c}}$ & $93.33 \mathrm{~b}$ \\
\hline PC & $66.66^{\mathrm{b}}$ & $40 \mathrm{~d}$ \\
\hline GB & $40^{\mathrm{a}}$ & $26.66 \mathrm{e}$ \\
\hline
\end{tabular}

AD: Agelanthus dodoneifolius ; TG: Tapinanthus globiferus ; TO: Tapinanthus ophiodes ; TB: Tapinanthus bangwensis ; TE: Tapinanthus belvisii ; PC: Phragmanthera capitata ; GB: Globimetula braunii.

On the same columns, the values assigned the same letters in superscript do not present statistically significant differences.

\section{Diversity indices of Loranthaceae of the Mandara Mountains}

The Shannon diversity index and the fairness of Pielou are higher on Mount 5 (0.328 and 0.120 respectively) which is made up of the Mount whose plain has an altitude greater than $800 \mathrm{~m}$ (table 9) while these indices are more weak on Mount 1 where the plain is less than $500 \mathrm{~m}, 0.317$ for the Shannon index and 0.113 for the equitability of Piélou. This means that the diversity of Loranthaceae is less dense in Mount 1 where the plain has a low altitude (ISH $=0.317$; EQ $=$ 0.113 ) compared to the Mount where the altitude of the plain is greater than $800 \mathrm{~m}(\mathrm{ISH}=0.328$; $\mathrm{EQ}=0.120)$.

Table 9: Loranthaceae diversity indices

\begin{tabular}{|c|c|c|c|c|c|}
\hline Parameters & M1 & M2 & M3 & M4 & M5 \\
\hline D & 536.32 & 544.13 & 559.34 & 573.99 & 584.44 \\
\hline ISH & 0.317 & 0.318 & 0.322 & 0.325 & 0.328 \\
\hline EQ & 0.113 & 0.113 & 0.115 & 0.117 & 0.120 \\
\hline
\end{tabular}

Mount $1(<500 \mathrm{~m}=\mathrm{M} 1+\mathrm{M} 2+\mathrm{M} 15) ;$ Mount $2([500 \mathrm{~m}-600 \mathrm{~m}[=\mathrm{M} 4+\mathrm{M} 5+\mathrm{M} 3) ;$ Mount $3([600 \mathrm{~m}-700 \mathrm{~m}[=\mathrm{M} 6+\mathrm{M}$ 7+M 13); Mount $4([700 \mathrm{~m}-800 \mathrm{~m}[=\mathrm{M} 8+\mathrm{M} 9+\mathrm{M} \mathrm{14})$; Mount $5(>800 \mathrm{~m}=\mathrm{M} 10+\mathrm{M} 11+\mathrm{M} 12) ; \mathrm{D}=\mathrm{Density} ; \mathrm{ISH}=$ Shannon's Index, EQ = Piélou's Equitability.

\section{DISCUSSION}

The taxonomic diversity of the host plants in our study is made up of 120 species belonging to 75 genera and grouped into 34 botanical families. These results are different from those of Houénon et al. [8] who obtained a diversity of 105 species distributed in 85 genera and 33 families. Our results reveal that Combretaceae and Mimosaceae are the most represented with 13 species each, either $10.83 \%$ for each family. Acacia is the most diverse genus with 10 species, or $8.33 \%$ of the host species. It is followed by Combretum and Ficus with 9 species each, either $7.5 \%$ of the host plants for each genus. 18 genera or $24 \%$ are reported monospecific. These results are different from those of Souare et al., [28] who obtained 34 species in the Diamare plain located in the same Sudano-Sahelian zone and from those of Houénon et al., [8] who showed in their study that Ficus is the most diverse genus with 5 species, or $5.9 \%$ of host plants. It is followed by Albizia with 4 species; either $4.7 \%$ or Leguminosaceae represent the highest family with 25 species, either 
$23.8 \%$. The differences observed would be due to the Hills which are rich in biodiversity. In all of the 120 listed host species, 68 species or $56.66 \%$ of the host species are parasitized by 1 or 2 parasitic species and represent the first class (I) which is the class of host species not very sensitive to parasitism of Loranthaceae. These species include: Haematostaphis barteri, Lannea acida, Lannea fruticosa, Sclerocarya birrea, Annona senegalensis, Hexalobus monopetalus, Vernonia thomsoniana, Stereospermum kunthianum, Adansonia digitata, Boswellia dalzielii, Commiphora africana, Piliostigma reticulatum, Capparis fascicularis, Boscia angustifolia etc. The second class (II) of sensitive host species consists of 8 species or $6.66 \%$ of the host species that represent the species susceptible to Loranthaceae parasitism. Among these species are: Balanites aegyptiaca, Tamarindus indica, Boscia senegalensis, Anogeissus leiocarpus, Dalbergia sisso'o, Acacia seyal, Ziziphus abyssinica, Citrus limon. The third class (III) of host plants consists of species highly sensitive to Loranthaceae parasitism. It is represented by 4 species or $3.33 \%$ of the host species. These include Ziziphus mauritiana, Khaya senegalensis, Azadirachta indica and Diospyros mespiliformis. These parasitic sensitivity classes are different from those of Houénon et al., [8] who indicated that in a sample of 105 identified host species, 79 species or $75.2 \%$ are infested with 1 or 2 species and represent class I (insensitive). They cited species such as Calotropis procera, Jatropha multifida, Khaya senegalensis, Persea americana, Triplochiton scleroxylon and Vitex doniana. Class II of sensitive hosts includes 20 species or $19.1 \%$ including Adansonia digitata, Ceiba pentandra, Irvingia gabonensis, Morinda lucida, Newbouldia laevis, Parkia biglobosa. Class III (highly sensitive) is rich in 4 species, or 3.8\%, namely: Acacia auriculiformis, Citus reticulata, Senna siamea and Tectona grandis and the last class which is class IV contains only Citrus sinensis which is the only planthost with a very high parasitic sensitivity.

The Mandara Mountains of Cameroon are home to the Loranthaceae flora. Of the 7 genera (Agelanthus, Englerina, Globimetula, Helixanthera, Phragmanthera, Tapinanthus and Viscum) and 25 species reported in Cameroon [29, 1, and 30], the Loranthaceae of this area group 4 genera (Agelanthus, Tapinanthus, Phragmanthera and Globimetula) or $57.14 \%$ and 7 species (T. globiferus, A. dodoneifolius, T. ophiodes, T. belvisii, T. bangwensis, $P$. capitata and G. braunii) or $26.92 \%$. These results do not corroborate those of Souare et al. [28], which identified 3 genera (Agelanthus, Tapinanthus and Phragmanthera) and 9 species. This taxonomic diversity of 4 genera and 7 is higher than that obtained by Ahamide et al. [31], who identified 3 genera (Globimetula, Phragmanthera and Tapinanthus) and 6 species in southern Benin, those of Boussim [32, 4] which inventoried 3 genera and 6 species in Burkina Fasso. Similarly, these results are superior to those of 2 genera and 3 species observed in
Lokomo in eastern Cameroon [13] and to those of 2 species of the same genus reported by Mony et al. [30] on the Logbessou Plateau in Douala, Cameroon but less than 6 genera and 19 species recorded in Côte d'Ivoire [33], 6 genera and 25 species examined in Cameroon [21] and those by Aka et al. [33] who identified eleven (11) species of parasitic plants in Côte d'Ivoire. In contrast, these results are close to those of Houénon et al. [8] who inventoried 4 genera and 10 species in the Guinean and Sudan-Guinean areas in Benin. The differences observed between these different results would be due to the altitudinal gradients of the study areas but also to climatic factors.

Our study reveals that the abundance of parasitic species is variable with a dominance of $T$. globiferus (73.38 \pm 37.48 tufts / ha). Our results are in contradiction with those of Amon et al. [35] who instead showed that $T$. bangwensis dominates in Côted'Ivoire and de Mony et al. [30] showing T. ogowensis dominates on the Logbessou plateau in Douala in Cameroon. This difference would be due to the fact that our study is focused on the hills while the previous studies were conducted in orchards. In the SudanoGuinean Savannas of the Adamawa Cameroon, Mapongmetsem et al. [22] found five species of parasitic plants on woody plants. Likewise, Boussim [32] observed five species and three genera of parasitic plants on Shea butter in the savannas of Burkina Faso. For Soro et al. [7], P. capitata is abundant at $74.82 \%$ in the forest zone of the sub-prefectures of Gagnoa and Ouragahio, in Côte d'Ivoire. Our study shows that the frequency of Loranthaceae species varies according to height difference, with hilltops as the preferred altitude. These results corroborate those obtained by Jiofack et al. [1] who found that Loranthaceae species evolve with altitude in the Bafou group in Cameroon. These authors also reported that Loranthaceae species are characterized by their variable expansion from one level to another depending on the temperature fluctuation in altitude.

\section{CONCLUSION}

The Mandara Mountains present a very rich specific diversity, likely to be parasitized by Loranthaceae. In total, we inventoried 120 host species belonging to 34 families and 75 genera. Combretaceae and Mimosaceae are the most represented each with 13 species, either $10.83 \%$ for each family. Acacia is the most diverse genus with 10 species, or $8.33 \%$ of the host species. 18 genera or $24 \%$ of the flora are reported to be monospecific. These Mountains abound over their area a taxonomic diversity of Loranthaceae of four (4) genera (Tapinanthus, Phragmanthera, Agelanthus and Globimetula) and 7 species (T. bangwensis, T. belvisii, T. globiferus, A. dodoneifolius, T. ophiodes, P. capitata and Globimetula braunii). From the point of view of the ecological distribution of Loranthaceae species, $T$. globiferus is the most represented (125.66 \pm 71.86 tufts / ha). It is followed by A. dodoneifolius (116.39 \pm 53.74 
tufts / ha). Then it is T. ophiodes which comes with an average density of $92.65 \pm 51.06$ tufts / ha; $T$. belvisii has an average density of $70.24 \pm 53.63$ tufts / ha. $P$. capitata has an average density of $57.74 \pm 27.2$ tufts / ha. $T$. bangwensis has an average density of $51.4 \pm$ 33.24 tufts / ha. G. braunii is the least represented parasitic species with an average density of $45.57 \pm$ 19.01 tufts / ha on the Mandara Mountains. The diversity and frequency vary according to the altitude and the slope of the hills. T. globiferus is most common in the Mandara Mountains, followed by $T$. dodoneifolius. These hemiparasites parasitize plants throughout their range in the Mandara Mountains. Knowledge of the diversity and altitudinal distribution of parasitic plants will contribute to their sustainable management on the Mandara Mountains in particular and on the Mountains of the World in general.

\section{ACKNOWLEDGMENT}

We would like to thank all the populations, the traditional and administrative authorities of the Mandara Mountains for their invaluable contribution to the realization of this study.

\section{REFERENCES}

1. Jiofack, T., Kemeuze, V., \& Pinta, J. (2007). Les Loranthaceae dans la pharmacopée traditionnelle $\mathrm{du}$ groupement Bafou au Cameroun. Cameroon J. Ethnobotany, 2, 29-35.

2. SAllE, G., TUQUET, C., \& Raynal-Roques, A. (1998). Biologie des Phanérogames parasites: Les phanérogames parasites. Comptes Rendus des Seances de la Societe de Biologie et de ses Filiales, 192(1), 9-36.

3. Dibong, S. D., Biyon, B. N., Obiang, N. E., Din, N., Priso, R. J., Taffouo, V. D., ... \& Akoa, A. (2010). Faut-il éradiquer les Loranthaceae sur les ligneux à fruits commercialisés de la région littorale du Cameroun?. International Journal of Biological and Chemical Sciences, 4(3).

4. Boussim, J. I. (2002). Les phanérogames parasites du Burkina Faso: inventaire, taxonomie, écologie et quelques aspects de leur biologie. Cas particulier des Loranthaceae parasites du karité.

5. Boudet, G., Lebrun, J. P., \& Demange, R. (1986). Catalogue des plantes vasculaires du Mali. CIRAD-IEMVT.

6. Wiens, D., Calvin, C., Wilson, C., \& Kirkup, D. W. (1998). Mistletoes of Africa. Royal Botanic Gardens, Kew.

7. Soro, K., Soro, D., N'guessan, K., Gnahoua, G. M., \& Traoré, D. (2010). Parasitisme des Loranthaceae sur les hévéas en zone forestière des souspréfectures de Gagnoa et d'Ouragahio, en Côte d'Ivoire. J. Anim. Plant Sci, 6(1), 597-604.

8. Houénon, G. J. (2012). Les Loranthaceae des Zones Guinéenne et Soudano-Guinéenne au Bénin et leur Impact sur les plantations
Agrumicoles (Doctoral dissertation, Thèse de Doctorat, Université d'Abomey-Calavi, AbomeyCalavi).

9. Boussim, I.J., Nayéré, M. (2009). Méthodes de lutte contre les Loranthaceae. Publication Server of Goethe University, 12. 27-35.

10. Koffi, A.A. (2014). Evaluation de l'incidence des Loranthaceae sur la productivité de Hevea brasiliensis (Kunth) Mull.Arg. à Anguédédou (Sud de la Côte d'Ivoire). Mémoire de DEA de Botanique, Université de Cocody, Abidjan, 52.

11. Massako. (2013). Parasitisme de Dacryodes edulis par le genre Tapinanthus et répartition de la myrmecofaune associée á Logbessou Plateau, Cameroun. Journal of Applied Biosciences, 68:5336 - 5348 .

12. Amon, A.D.E., Soro, D., Traoré, D. (2015). Evaluation de l'infestation des Loranthacées sur les ligneux des agroécosystèmes de la région du SudComoé (Côte d'Ivoire). International Journal of Biological and Chemical Sciences, 9(4): 18221834.

13. Azo'o, J., Tchatat, M., Mony, R.et Dibong, S.D. (2013). Parasitisme et ethnobotanique des Loranthaceae à Lokomo (Est-Cameroun). Journal of Animal \&Plant Sciences, 19(2): 2922-2932.

14. Ngotta, B. J., Dibong, S. D., Taffouo, V. D., Ondoua, J. M. et Bilong, P. (2015). Niveau de parasitisme des hévéas par les Loranthaceae dans la région du Sud-ouest Cameroun, Journal of Applied Biosciences, 96:9055 - 9062.

15. Dibong, S.D., Din, N., Priso, R.J., Taffouo, V. D., Fankem, H., Salle, G. et Amougou, A. (2008). Parasitism of host trees by the Loranthaceae in the region of Douala Cameroon). African journal of Environmental Science and Technology, 2(11): 371 -378 .

16. Gerhard, M.K. (2003). The way of the beer : ritual reenactment of historyamong the Mafa, terracefarmers of the Mandara Mountains (North Cameroun), MandarasPublishing, Londres, 408.

17. Ekhaise, F. O., Isitor, E. E., Idehen, O., \& Emoghene, A. O. (2010). Airborne microflora in the atmosphere of an hospital environment of University of Benin Teaching Hospital (UBTH), Benin City, Nigeria. World J Agric Sci, 6(2), 16670 .

18. Wahab, S. (2010). China earns newfound respect with Mashair. Arab News.

19. Ogunmefun, O. T., Fasola, T. R., Saba, A. B., \& Oridupa, O. A. (2013). The ethnobotanical, phytochemical and mineral analyses of Phragmanthera incana (Klotzsch), a species of mistletoe growing on three plant hosts in SouthWestern Nigeria. International journal of biomedical science: IJBS, 9(1), 33.

20. Dibong, S. D., Obiang, N.L.E., Ndongo, D., Priso, R. J.,Taffouo, V., Fankem, H., Salle, G. et Akoa, A. (2009). Les Loranthaceae: un atout pour l'essor 
de la pharmacopée traditionnelle au Cameroun, Int. J. Biol. Chem. Sci., 3(4): 746-754.

21. Balle, S. (1982). Loranthacées. In Flore du Cameroun: Satabie B, Leroy JF (Editors), Yaoundé, 82.

22. Mapongmetsem, P.M., M.H. Motalindja., \& Nyomo. (1998). Eyes on the enemy. Identifying parasitic plants of wild fruit trees in Cameroon. Agroforest. Today, 10(3): 10-11.

23. Ibrahima, A., Mapongmetsem, P.M., Motalindja, M.H., Moussou, L., \& Nyomo. (2006). Vascular epiphytes and parasitic plants on Vitellaria paradoxa Gaertn. (Sapotaceae) in the Sudanoguinea savannas of Ngaoundere, Cameroon. Selbyana, 27(1): 72-78.

24. Maïnam, F. (1999). Modelling soil erodibility in the semi arid zone of Cameroon, Assessmentof interillerodibilityparameter for mappingsoilerosionhazard by means of GIS techniques in the Gawar area. Ph.D. Thesis. Faculty of Sciences, University of Ghent. The Netherlands, 387.

25. BUCREP. (2005). Rapport national sur l'état de la population, enjeux et défis d'une population de 20 millions au Cameroun en 2005, édition 2005, 106.

26. Arbonnier, M. (2000). Arbres, arbustes et lianes des zones sèches d'Afrique de l'Ouest. CIRADMNHN-UICN, Montpellier. 541.

27. Shannon, C., \& Weaver, W., (1949). The mathematical theory of communication.Urbana, IL:University of Illinois Press, 63.

28. Souare, K., Todou, G., Froumsia, M., Divine, T. M., Nnanga, J. F., Tchobsala., and Ibrahima, A.
(2020). Floristic diversity of Loranthaceae Family and their potential host species in Sudano-sahelian zone of Cameroon: case of Diamare plain in FarNorth Region. International Journal of Biological and Chemical Sciences, 14(3): 896 - 915.

29. Balle, S. (1986). Flore du Cameroun, 23. Loranthaceae (Éds B. Satabié et J.-F. Leroy). Yaoundé, Cameroun, Dgrst, 82.

30. Mony, R., Tchatat, M., Massako, F., \& Dibong, S.D. (2014). Parasitisme du safoutier par les Tapinanthus au plateau de Logbessou (Douala, Cameroun), Tropicultura, 32(4) : 177-182.

31. Ahamide, D.Y.I., Tossou, M.G., Adomou, A.C., Houénon, G.J., Yédomonhan, H., Akoègninou, A. (2015). Diversité, impacts et usages des Loranthaceae parasites de Cola nitida (Vent.) Schott. \&Endl. au Sud-Bénin. Int. J. Biol. Chem. Sci., 9(6): 2859-2870.

32. Boussim, I.J. (1991). Contribution à l'étude des Tapinanthus parasites du karité au Burkina Faso. Thèse de doctorat de 3e cycle, 152.

33. Aka, R., Danho, F.R.N., Klotioloma, C., Kouamé, F., N'guessan, et Kebe, I. B. (2016). Inventaire

34. Boussim, J. I., \& Médah, N. (2009). Méthodes de lutte contre les Loranthaceae. Flora et Vegetatio Sudano-Sambesica, 12, 27-35.

35. d'Ivoire, C. (2010). Les Loranthaceae: plantes vasculaires parasites des arbres et arbustes, au Sudest de la Côte d'Ivoire. Journal of Applied Biosciences, 25, 1565-1572.

36. Thirakul, S. (1990). Manuel de dendrologie des savanes boisées du Cameroun. Québec, Canada, Poulin Thériault. 